\title{
Proper Attitude to Ketamine
}

\author{
Yuguang Huang,MD \\ Professor and Chairman \\ Department of Anesthesiology \\ Peking Union Medical College Hospital
}

"A medical drug is always potentially toxic, but the key point is how to use it properly". I still remember what my pharmacological professor emphasized when we studied in medical school in 1978. The discussion on ketamine as a medication in this issue of the Translational Perioperative and Pain Medicine is an excellent one for a proper position and proper usage of ketamine in medicine. ${ }^{1}$

Ketamine or Ketalar, was a quite familiar yet unforgettable drug in my mind since I graduated from medical school and touched down on the road of clinical anesthesia from 1983. In those decades ketamine was the most appreciated choice for clinical general anesthesia without endotracheal intubation, especially in children and short surgery including burns and trauma cases. My chief resident experience in a group of trauma patients with hemorrhagic shock made me feel in awe that anesthesia was induced just with ketamine and pancurounim, followed by endotracheal intubation in such an emergency.

Because of the poor economic situations before 1990's, the anesthesia department was equipped with shortage of sophisticated machines and monitors in a majority of Chinese hospitals. The choices of anesthesia were also rather limited. General anesthesia was mainly conducted with patients' spontaneous respiration and the airway was not secured with intubation throughout the surgery. Regional (Local) anesthesia including epidural anesthesia accounted for more than $80 \%$ of total cases then. In that background, ketamine was very helpful for general anesthesia or epidural anesthesia if regional blockade could not meet the surgical needs. In the county-level hospitals, ketamine even solved all daily clinical problems for anesthesia but with high perioperative mobility and mortality.

In my memory, I was impressed by the high incidence of complications related to ketamine. The special ketamine issue reported by the Clinical Journal of Anesthesia in 1980's, focused on the complications of ketamine from the different parts of Mainland China. However, the actual reasons after analysis were related not to the drug per se but mainly to the poor airway management and vital sign monitoring.
With China's Open Door Policy and economic booming after 1990's, the anesthesia working conditions improved dramatically year by year. More choices of clinical drugs and anesthesia techniques became practically available. Ketamine still plays an important role in anesthesia and even more in analgesia. The ketamine related complications rapidly decreased partly because of routine endotracheal intubation and better monitoring for general anesthesia.

A research update suggested that ketamine might potentiate the analgesic effect as a NMDA receptor antagonist. It can reduce the peripheral and central sensitization by means of protecting glutamate from NMDA receptors. As a result, ketamine was encouraged as a good supplement to general anesthesia and multi model analgesia. Patient-Controlled Analgesia (PCA) was introduced into Chinese medical practice for surgical patients by the Peking Union Medical College Hospital in 1994. In the early 2000's ketamine was combined with strong opioids for PCA as a kind of routine. Ketamine is also an important agent for pain research and is still a hot topic for research on the mechanism of neuropathic pain.

It is obvious that ketamine is a valuable medical drug based on clinical and research evidence. On the other hand, drug abuse, including ketamine abuse, is an international concern. It was called "ketamine powder" by drug abusers and is why ketamine management became more strictly controlled by prescribed policy to protect it from abuse. Hence, this paradoxical situation requires us to weigh the pros and cons of ketamine usage in the future. My personal opinion is that the government has both responsibilities either to encourage more drug choices for clinical needs and to protect medical drugs from social abuse. We should exercise professionalism to help policy makers make rational choices, from which we can do even more.

Ketamine is a good example of how it can be a drug for medical purpose as well as a drug for abuse. This is still a tough issue and needs a long term international collaborative effort to solve. 
Address for correspondence: Yuguang Huang,MD; Professor and Chairman, Department of Anesthesiology, Peking Union

Medical College Hospital, Beijing 100730.

Email: garybeijing@163.com

\section{Editor}

Renyu Liu, MD; PhD, Associate Professor

Director of Preoperative Medicine, Department of Anesthesiology and Critical Care, Perelman School of Medicine at the University of Pennsylvania.liur@uphs.upenn.edu

\section{Disclosure of Funding}

None

Additional publication details

Journal short name: Transl Perioper \& Pain Med

Received Date:June 15, 2015

Accepted Date: July 1, 2015

Published Date: July 15, 2015

Transl Perioper \& Pain Med 2015; 2(2):18-19

\section{Citation and Copyright}

Citation: Hung Y. Proper attitude to ketamine. Transl Perioper \& Pain Med 2015; 2(2): 18-19

Copyright: (C) 2015 Yuguang Huang, MD, PhD. This is an open-access article distributed under the terms of the Creative Commons Attribution License, which permits unrestricted use, distribution, and reproduction in any medium, provided the original author and source are credited.

References

1. Meng L, Li J, Lu Y, Sun D, Tao Y, Liu R, Luo J. Ketamine - A Multifaceted Drug. Transl Perioper \& Pain Med 2015; 2(2): 20-26 